\title{
ŚWIADECTWO, AUTORYTET I MĄDROŚĆ JAKO ŹRÓDŁA WIEDZY
}

Problem „źródeł wiedzy" wyraża się w pytaniu, skąd pochodzą dane wykorzystywane w ludzkich czynnościach epistemicznych. Do źródeł wiedzy zalicza się: spostrzeganie zmysłowe (percepcję zmysłową) w różnych jej odmianach, spostrzeganie wewnętrzne, zwane doświadczeniem wewnętrznym, introspekcją samoświadomością (rzadziej refleksją), pamięć, aprioryczne źródła wiedzy (o ile takie istnieją), a także czyjeś świadectwo oraz autorytet. Do źródeł wiedzy należy też zaliczyć różnego rodzaju rozumowania, które, zasadniczo rzecz biorąc, dzielą się na dedukcyjne (koniecznościowe) i probabilistyczne ${ }^{1}$.

Termin „źródło" można rozumieć w sensie "genezy” oraz znaczeniu „podstawy uprawomocnienia". Przekonanie, że niebo jest teraz niebieskie, pochodzi (geneza) ze spostrzegania zmysłowego i jedocześnie podstawą jego uprawomocnienia jest to, że teraz spostrzegam niebieskie niebo, ale nie tylko to jest podstawą uprawomocnienia tego przekonania, gdyż aby być przekonanym o niebieskości nieba, muszę w tle akceptować także inne przekonania, np. o tym, że jestem w stanie odróżniać kolory, że moje zmysły funkcjonują poprawnie itd. Tak więc nawet $\mathrm{w}$ tej prostej sytuacji okazuje się, że geneza i podstawa uprawomocnienia są dwiema różnymi rzeczami.

W odróżnieniu od wyżej wymienionych źródeł wiedzy problematyka świadectwa (testimony) jest nowa w epistemologii. Choć pewne elementy rozważań na temat jego roli w strukturze wiedzy ludzkiej pojawiły się już u Davida Hume'a i Thomasa Reida, to za początek osobnej subdyscypliny

${ }^{1}$ Por. (Audi 2002); por. też (Bernecker, Prichard, 2011), gdzie cześć czwarta książki nosi tytuł "Rodzaje wiedzy” (Kinds of knowledge), przy czym pojęcie rodzajów wiedzy jest tam rozumiane szerzej niż pojęcie źródeł wiedzy, a mianowicie do rodzajów wiedzy zostały zaliczone: wiedza indukcyjna, aprioryczna, percepcyjna, doświadczenie wewnętrzne (self-knowledge), wiedza pamięciowa, semantyczna, logiczno-matematyczna, estetyczna, moralna i religijna. 
epistemologii, zajmującej się problemem świadectwa, uznawana jest książka C.A.J. Coady'ego Testimony z 1992 roku².

Rola czyjegoś świadectwa w strukturze wiedzy każdej osoby jest ogromnie ważna: większość tego, co wiemy o świecie, wiemy dzięki świadectwu innych ludzi, poczynając od świadectw historycznych, poprzez świadectwa poszczególnych osób w różnych dziedzinach wiedzy naukowej, aż po świadectwa dotyczące życia codziennego, gdy np. pytamy o godzinę lub o kierunek, w którym należy się udać, aby dotrzeć do miejsca, którego poszukujemy. Prawdziwości części tych świadectw nie jesteśmy sami w stanie sprawdzić, gdyż stany rzeczy, o które chodzi, należą do przeszłości, natomiast samodzielne sprawdzenie wiedzy naukowej, choć w zasadzie możliwe, jest praktycznie niewykonalne. Nasza wiedza o świecie składa się w ogromnej swej części z wiedzy przekazywanej przez inne osoby. W takich okolicznościach jak postępowanie sądowe czyjeś świadectwo (testimony) może stanowić jeden z dowodów lub jedną $z$ racji (evidence) branych pod uwagę przez sąd. W dalszym ciągu świadectwo będzie tu rozważane niezależnie do restrykcji nakładanych przez sąd na to, co może być uznane za świadectwo, a co nie zasługuje na to miano. Głównie będzie tu chodziło o proste sytuacje, gdy np. ktoś pytany kierunek w nieznanym mieście odpowiada na nasze pytanie.

Świadectwo należy do niesamodzielnych źródeł wiedzy, gdyż jest zależne genetycznie (przyczynowo) od percepcji, doświadczenia wewnętrznego, pamięci w ten sposób, że nie można o czymś komuś zaświadczać, jeśli się samemu wcześniej tego czegoś nie spostrzegło, nie pamiętało itd. Głównym jednak tematem współczesnej epistemologii świadectwa jest pytanie, czy w aspekcie uzasadniania świadectwo jest samodzielnym źródłem przekonań i zdobywania wiedzy, czy też zawsze podmiot przyjmujący czyjeś świadectwo musi być w stanie zbadać przynajmniej wiarygodność osób zaświadczających o czymś. Antyredukcjoniści w kwestii statusu podstaw epistemicznych świadectwa, zwani też fundacjonalistami, twierdza, że świadectwo stanowi samodzielne źródło nabywania wiedzy, natomiast ich przeciwnicy, redukcjoniści, wskazują na konieczność uwzględnienia innych środków, którymi mogą być wiedza indukcyjna na temat wiarygodności osób zaświadczających o czymś, wiedza o tym, kogo i w jakich okolicznościach można uznać za osobę wiarygodną itp.

Przykładem stanowiska antyredukcjonistycznego może być zasada akceptacji sformułowana przez Tylera Burge'a (ur. 1946), a mianowicie: „Podmiot ma prawo do akceptacji czegoś jako prawdy, jeśli zostało to mu przedstawione jako prawda i jest to dla niego zrozumiałe, chyba że ma

${ }^{2}$ Por. (Coady 1992; Gelfert 2014). 
mocniejsze racje, aby tak nie czynić" (Burge 1993, s. 467). Takie stanowisko wymaga różnego rodzaju zastrzeżeń i odpowiednio obudowania. Zanim jednak to nastąi, trzeba zwrócić uwagę, że chodzi w nim o przeciwstawienie się tzw. globalnemu redukcjonizmowi twierdzącemu, że zawsze musimy badać prawdziwość czyjegoś świadectwa. Wydaje się to jednak nie tylko niewykonalne, ale też niemożliwe. Ukazaniu tej niemożliwości ma służyć następujący argument, tzw. argument transcendentalny, czyli taki, w którym wykazuje się, że zwolennik redukcjonizmu musi założyć to, czemu chce przeczyć.

Możemy sobie wyobrazić kogoś, kto próbuje odgadnąć język jakiegoś nieznanego dotąd plemienia, przy czym jest on zdany wyłącznie na sekwencje dźwięków wydanych przez ludzi należących do tego plemienia. Gdy tubylec w obecności pewnego rodzaju przedmiotów wydaje dźwięki, które znaczą w języku badającego: „To jest gorzkie”, to badacz może zacząć sprawdzać, czy wydawane dźwięki rzeczywiście są wypowiadane w obecności tych przedmiotów, które według niego samego są gorzkie. Aby tak jednak zaczać postępować, z góry musi uznać, że wydawane dźwięki są zasadniczo prawdziwym świadectwem tego, co członkowie badanego plemienia robia, gdy napotykają gorzkie przedmioty (Stevenson 1993).

Z powyższego przykładu ma wynikać, że globalny redukcjonizm jest niemożliwy. Należy zauważyć, że powodem niemożliwości całkowitego (globalnego) zredukowania zaufania do świadectwa innych osób jest to, że nie mamy bezpośredniego dostępu do ich stanów mentalnych, a więc ostatecznie musimy założyć, że przynajmniej w większości wypadków to, co mówią jest prawdziwym świadectwem sprawozdającym ich przekonania.

Niewykonalność globalnej redukcji zaufania do tego, co mówią inni, może prowadzić do tezy, że przynajmniej w poszczególnych wypadkach, czyli lokalnie, powinniśmy monitorować, czy zaświadczająca o czymś osoba wykazuje oznaki prawdomówności, czy jest godna zaufania, czy nie wygląda na kogoś nierzetelnego. Również jednak i taki lokalny redukcjonizm jest niemożliwy do konkluzywnego przeprowadzenia, gdyż oznaki, którymi kierujemy się, próbując ustalić czyjąś rzetelność, są większości wypadków ogólnikowe, zależą od doświadczenia i znajomości ludzkich charakterów i zachowań, a z kolei tego rodzaju znajomość różna jest u różnych ludzi itd.

Z powyższych rozważań nie powinno jednakże wynikać, że musimy być łatwowierni w stosunku do tego, co mówią inni. Istnieje bowiem wiele powodów, aby ufać mówiącym do nas osobom. Po pierwsze, wiemy z doświadczenia, że w większości ludzie mówią prawdę, gdyż od tego zależy działanie w świecie, szybko zatem zauważylibyśmy 
błędy w przekazywanych nam informacjach. Po drugie, prawdomówność funkcjonuje jako norma społeczna, jest ona założeniem praktyki komunikacji lingwistycznej, a przeciwstawienie się tej normie może podkopać ogólne zaufanie do kogoś przekazującego fałszywe informacje. Kłamanie, wykręty itp. są bardziej ryzykowne niż zwykła szczerość. Po trzecie, istnieją sankcje wymierzone w osoby przekraczające normę prawdomówności, co szczególnie jest widoczne w wypadku małych społeczności. Kłamanie wiąże się z utratą reputacji, natomiast w nauce barierą dla kłamstwa jest powtarzalność doświadczeń, publiczność tego, co się głosi, oraz opinie (recenzje) wydawane przez osoby kompetentne. Po czwarte, wiemy, że kłamanie rzadko się opłaca, kłamanie dla zabawy zaś jest rodzajem szaleństwa. Po piąte, szybko uczymy się, jak rozpoznawać rodzaje mówiących do nas osób, uczymy się, jak dalece zasługują one na przyznanie im cechy wiarygodności. Po szóste, potrafimy w pewnej mierze rozpoznać wiarygodność osób świadczących o czymś w ten sposób, że wiedza słuchającego filtruje wiele rzeczy, które nie zasługują na przyjęcie.

Jako źródło wiedzy można potraktować także autorytet. Nie zawsze świadectwo ma charakter autorytetu, choć w minimalnym sensie element autorytetu występuje w każdym bezpośrednim świadectwie: gdy pytam kogoś w nieznanej mi okolicy o drogę, to informując mnie, osoba ta staje się jest dla mnie autorytetem w dziedzinie wiedzy, której poszukuję. Sytuacja odwrotna nie zachodzi, gdyż wielu osób, które mógłbym potraktować jako autorytet $\mathrm{w}$ pewnej dziedzinie, nie spotykam bezpośrednio, aby w modelowej sytuacji bezpośredniego kontaktu mogły mi zaświadczyć o czymś. Każdy z nas jest dla innych osób autorytetem, jeśli chodzi o własne doznania cielesne i psychiczne.

Autorytet różnicuje się dziedzinowo: $w$ języku potocznym mówimy bowiem o autorytetach w określonych dziedzinach wiedzy lub umiejętności, a więc o autorytecie naukowym, moralnym, religijnym, politycznym, o autorytecie $\mathrm{w}$ jakiejś dziedzinie medycyny, rzemiosła, sportu itd. Problemem dla filozofii jest to, czy pojęcie autorytetu da się tak zinterpretować, aby można było powiedzieć, że autorytet określonych osób lub instytucji może być potraktowany jako źródło wiedzy.

Na pewno na początku należy odróżnić autorytet jako siłę przymusu od autorytetu jako - ewentualnego - źródła wiedzy. Józef Maria Bocheński wprowadził $\mathrm{w}$ tym kontekście rozróżnienie pomiędzy autorytetem epistemicznym i deontycznym (Bocheński 1990, s. 125). Autorytet epistemiczny dotyczy wiedzy, deontyczny zaś jest mocą wydawania poleceń, rozkazów itp. Należy jednak sądzić, że autorytet deontyczny jest wyłącznie siłą przymusu, usankcjonowanym społecznie uprawnieniem do wydawania rozkazów. Choć tego rodzaju uprawnienie nazywamy potocznie 
autorytetem, to jednak ono nim nie jest. Przełożony wydający rozkazy $\mathrm{w}$ wojsku nie jest dla podkomendnego autorytetem $\mathrm{w}$ określonej dziedzinie wiedzy (epistemicznym autorytetem), lecz wyłącznie ma nad nim władzę. Może oczywiście być tak, że autorytet jako siła przymusu, jako uprawnienie do wydawania rozkazów łączy się z autorytetem epistemicznym $\mathrm{w}$ ten sposób, że osoba wydająca w wojsku rozkazy jest jednocześnie autorytetem epistemicznym w dziedzinie, do której się odnosi, np. w dziedzinie strategii lub taktyk prowadzenia wojny.

W dalszym ciągu będę dążył do wykazania, że autorytet epistemiczny, a więc autorytet niepolegający na mocy wydawania poleceń, jest podstawą autorytetu we wszystkich innych dziedzinach, a więc autorytet epistemiczny jest podstawą autorytetu moralnego, estetycznego, religijnego, politycznego itd. Tego rodzaju teza wymaga oczywiście określenia, czym jest autorytet epistemiczny.

Należy wyjść od stwierdzenia, że wszyscy ludzie z natury dążą do prawdy (wiedzy). Inaczej to ujmując i uogólniając, wszystkie istoty wyposażone w rozum dążą do prawdy (wiedzy), gdyż jedynym właściwym przedmiotem rozumu są prawda i wiedza. Rozum niejako "żywi się prawdą". Co innego mogłoby być celem rozumu niż prawda? Jeśli tak jest, to za autorytet epistemiczny będę uznawał te osoby, które mogą mi pomóc w moim dążeniu do prawdy: jeśli uznaję kogoś za autorytet $\mathrm{w}$ pewnej dziedzinie wiedzy, to czynię tak dlatego, że osoba ta może mi pomóc $\mathrm{w}$ moim dążeniu do prawdy ${ }^{3}$. To pragnienie prawdy (wiedzy) nie dotyczy tylko codziennych spraw życiowych, nie dotyczy też wyłącznie teoretycznej wiedzy o różnego rodzaju faktach czy posiadania określonych umiejętności, ale także odnosi się do hierarchii celów oraz do tego, co powinienem uznawać za cele najwyższe. Tak więc autorytet epistemiczny odnosi się również do dziedziny wartości (dziedziny aksjologicznej).

Dążenie do prawdy i wiedzy może być wyłącznie wtedy zrealizowane, gdy podmiot jest uczciwy i sumienny w tym dążeniu. Nawet gdy ktoś wykazuje dobrą znajomość jakiejś określonej dziedziny, a ja oceniam, że nie jest on uczciwy i sumienny, to nie będę go uznawał za autorytet. Lekarz, naukowiec, duchowny itd., którzy dobrze znają swoją dziedziny, natychmiast przestają być kandydatami do bycia autorytetami, gdy

${ }^{3}$ Por. (Trinkaus-Zagzebski 2012). Trinkaus-Zagzebski zmierza w nie tylko do ukazania różnych odmian autorytetu i pojęcia zaufania, lecz także przede wszystkim do epistemologicznego ugruntowania pojęcia autorytetu. Podstawą tego ugruntowania ma być wspólne wszystkim ludziom pragnienie wiedzy oraz zaufanie do własnych władz poznawczych. Jeśli ktoś ufa własnym władzom poznawczym, to uznając że inni ludzie są podobni do niego $\mathrm{w}$ aspekcie intelektualnym, nie ma on zasadniczego powodu, aby nie ufać innym, kompetentnym danej dziedzinie podmiotom. 
stwierdzę, że są nieuczciwi i niesumienni ${ }^{4}$. Wynika to stąd, że gdy ja sam dążę uczciwie i sumiennie do prawdy i wiedzy, to nie mogę potraktować jako autorytety wszystkich, których oceniam jako niespełniających tego warunku. Oceniam, że z punktu widzenia mojego pragnienia prawdy i wiedzy oraz ze względu na moje dążenie do prawdy i wiedzy osoby niedążące uczciwie i sumiennie do tych wartości nie mogą być mi pomocne $\mathrm{w}$ realizacji mojego pragnienia i dążenia. W tym sensie warunkiem bycia kandydatem do autorytetu w każdej dziedzinie, oprócz dobrej znajomości tej dziedziny, jest moralne wymaganie uczciwości i sumienności. Z punktu widzenia podmiotu oceniającego kandydat do bycia autorytetem nie musi być nieomylny, nie musi także być bez żadnej skazy moralnej (co byłoby wymaganiem nierealistycznym), lecz musi posiadać cnotę uczciwości i sumienności.

Autorytetem jest więc dla mnie ktoś, kogo oceniam jako uczciwego w dążeniu do prawdy i wiedzy w określonej dziedzinie i jako kogoś, kto posiada lepszą znajomość tej dziedziny ode mnie. Jako taki może być mi pomocny w moim dążeniu do prawdy i wiedzy. Każdy autorytet musi więc spełniać warunek dotyczący wartości moralnych lub cnót moralnych (uczciwość i sumienność), jak również musi posiadać lepszą znajomość określonej dziedziny. Autorytet może być stopniowalny, zależnie od różnych okoliczności: dla studenta pierwszego roku autorytetem może student lat końcowych, lecz większym autorytetem w odniesieniu do przedmiotu studiów będzie profesor.

Autorytet $\mathrm{w}$ dziedzinie moralnej, religijnej czy nawet politycznej zawsze polega ostatecznie na autorytecie epistemicznym. Ze względu na ukształtowane $w$ czasach nowożytnych poczucie autonomii każdej jednostki ludzkiej i ideę polegania na sobie samym każdego rozumnego indywiduum większość z nas nie jest skłonna do akceptacji pojęcia autorytetu moralnego. W myśl idei absolutnej autonomii i polegania wyłącznie na sobie samym żaden nauczyciel, duchowny czy ktoś inny nie może być dla mnie autorytetem np. w kwestii tego, czy eutanazja jest czymś złym, czy czymś dobrym. Każdy musi to rozstrzygnąć wyłącznie we własnym sumieniu, polegając wyłącznie na samym sobie. Zarazem jednak autorytetem moralnym może być dla mnie ktoś, kto twierdzi, że zna najwyższe cele, do których jednostki ludzkie powinny dążyć, że umie je uzasadnić, oraz, co najważniejsze, ktoś, kto swoim życiem zaświadcza o uczciwości i sumienności zarówno swoich przekonań, jak

4 „Uznanie większej kompetencji i prawdomówności podmiotu w dziedzinie jest koniecznym warunkiem autorytetu epistemicznego. [...] kłamca nie może być autorytetem, bo w pojęciu autorytetu epistemicznego zawiera się już zaufanie do podmiotu" (Bocheński 1993, s. 243-244). 
również swoich dążeń. Te dwa czynniki, a więc znajomość najwyższych celów w dziedzinie moralnej oraz świadczenie własnym życiem, mogą być podstawą uznania przez mnie, że taka osoba jest dla mnie autorytetem, czyli kimś, kto pomoże mi w moim uczciwym i sumiennym dążeniu do prawdy w dziedzinie moralnej.

Podobnie jest $\mathrm{w}$ obszarze religijnym. Tutaj również autorytet musi ostatecznie opierać się na autorytecie epistemicznym, a więc na twierdzeniu, że zna się najwyższe cele, do których człowiek powinien dążyć. $\mathrm{W}$ wypadku teistycznych systemów religijnych tym najwyższym celem jest Bóg. Tak jak w dziedzinie moralnej, tak też i tu oprócz znajomości danej dziedziny wchodzą w rachubę uczciwość i sumienność w dążeniu do prawdy oraz $\mathrm{w}$ zaświadczenie własnym sposobem życia o tej uczciwości. Gdy te warunki są spełnione, wtedy taka osoba może być dla mnie autorytetem religijnym, to znaczy kimś, kogo ze względu na moje własne uczciwe i sumienne dążenie do prawdy mogę uznać za pomocnego w odkryciu tej prawdy. Wspólnoty religijne, w których istotną rolę odgrywa przekazywanie tradycji, czerpią swój autorytet ze źródła, jakim jest objawienie, a więc ostatecznie ze źródła, jakim jest Bóg jako objawiający się. Mimo to jednak roszczenie do bycia autentycznym przekazicielem ostatecznego autorytetu objawienia może dokonywać się tylko przez uczciwość i sumienność w dążeniu do prawdy oraz przez świadectwo życia. Istotną rolę w kształtowaniu się we mnie poczucia, że ktoś jest dla mnie autorytetem $\mathrm{w}$ dziedzinie religijnej, odgrywa doświadczenie czyichś heroicznych czynów, doświadczenie bycia pociągniętym przez określony wzorzec. Autorytet wspólnot religijnych "zawieszony" jest ostatecznie na uczciwości i sumienności przynajmniej niektórych osób należących do nich oraz na heroizmie ich życia.

Gdy w dziedzinie politycznej pominiemy autorytet jako czystą siłę przymusu, to i tu autorytetem mogą być tylko te osoby lub instytucje, które twierdza, że znają ostateczne cele, do jakich warto jest dążyć w życiu wspólnoty państwowej, narodowej lub innej. Takimi celami mogą być osiągnięcie najwyższej możliwej sprawiedliwości życia wspólnotowego, zmniejszanie ubóstwa, zmniejszenie poziomu cierpienia w społeczeństwie, podniesienie poziomu moralnego itp. Patrząc od tej strony, autorytet polityczny polegałby nie wyłącznie na legitymizacji, którą stanowi demokratyczny wybór, lecz także na tym, że przedstawiciele władzy lub klasy politycznej twierdza, że znają najwyższe cele, do jakich może dążyć dana społeczność, oraz własną uczciwością i sumiennością zaświadczają o autentyczności tych przekonań. A więc autorytetem politycznym będzie dla mnie ktoś, kogo ze względu na moje uczciwe i sumienne dążenie do prawdy oceniam jako mogącego mi być pomocnym w rozpoznaniu najwyższych celów życia społecznego. Tak powszechne 
w ostatnich czasach rozczarowanie życiem politycznym i tzw. upadek autorytetów politycznych biorą się z - często bardzo szybkiego - rozpoznania nieuczciwości i niesumienności osób tworzących klasę polityczną.

W dość powszechnym odczuciu mądrość i autorytet znajdują się blisko siebie, nie każdej jednak osobie, której skłonni bylibyśmy przyznać miano autorytetu w określonej dziedzinie, przypisalibyśmy cechę mądrości, dotyczy ona bowiem nie określonej dziedziny, lecz całości życia ludzkiego. Niekiedy za mądrość uważana jest znajomość ludzkich charakterów, lecz takie rozumienie mądrości jest zbyt wąskie, gdyż odnosi się wyłącznie pewnej określonej dziedziny i niekiedy zbliża się do pojęcia sprytu życiowego.

Łączono mądrość z teoretyczną kontemplacją (Arystoteles), ze znajomością ostatecznych przyczyn (św. Tomasz z Akwinu) lub uznawano za nią zgodność między dążeniem woli a celem ostatecznym, jakim jest najwyższe dobro (Immanuel Kant). Wykorzystując dotychczas przeprowadzone rozważania na temat pojęcia autorytetu, należy stwierdzić, że mądrość dotyczy całości życia ludzkiego i znajomości jego ostatecznych celów, a obdarzyć cechą mądrości można tę osobę, która uczciwie i sumiennie dąży do rozpoznania ostatecznych celów życia ludzkiego oraz swoim życiem zaświadcza, że takie cele rozpoznała. Ze względu na znajomość ostatecznych celów życia ludzkiego oraz na uczciwe i sumienne dążenie do rozpoznania takich celów osoba dysponująca mądrością może stać się autorytetem dla innych osób, które poszukują odpowiedzi na pytanie o ostateczne cele życia ludzkiego. Osoba, której chcielibyśmy przypisać cechę mądrości, uważa, że zna ostateczne cele życia ludzkiego i ze względu na nie może oceniać wszystkie działania ludzkie.

Jeśli ktoś twierdzi, że ostateczne cele życia ludzkiego kończą się wraz życiem w tym świecie, w świecie materialnym, oraz gdy taka osoba swoją uczciwością i sumiennością zaświadcza o autentyczności własnych poglądów, to można uznać, że jej wskazówki co do tego, jak należy żyć, pochodzą z cechy mądrości, jaką posiada. Przypisanie komuś cechy mądrości nie pociąga za sobą uznania, że istnieją pozaświatowe cele ludzkiego życia, jednakże tego rodzaju mądrość wyłącznie w obrębie ludzkiej skończoności wydaje się ostatecznie mądrością pesymistyczną.

Gdy znajomość ostatecznych celów życia ludzkiego zostanie zastosowana do poszczególnych sytuacji życiowych, to mądrość można nazwać aksjologiczną duchowością ${ }^{5}$. Jest ona zdolnością do aksjologicznego wglądu we wszystkie sytuacje i stany rzeczy związane z ludzkim życiem oraz zdolnością do ich oceny ze względu na ostateczne cele. Jak jednak

5 Takie określenie „mądrości” biorę, modyfikując je, od Nicolaia Hartmanna; por. (Hartmann [1925] 1949, s. 427-432). 
należy sądzić, tego rodzaju zdolność do wglądu we wszystkie sytuacje i stany rzeczy związane z ludzkim życiem musi ostatecznie prowadzić do kontemplacyjnego zwrotu ku najwyższym ideom, łączyć się z „pprzeczuciem" ostatecznych przyczyn oraz z antycypacją najwyższego dobra.

\section{Bibliografia}

Audi R. (2002), The Sources of Knowledge, [w:] P. Moser (red.), The Oxford Handbook of Epistemology, Oxford University Press, Oxford, s. 71-94.

Bernecker S., Prichard D. (red.) (2011), The Routledge Companion to Epistemology, Routledge, New York.

Bińczyk E. (2013), Świadectwo i autorytet, [w:] R. Ziemińska (red.), Przewodnik po epistemologii, Wydawnictwo WAM, Kraków, s. 311-339.

Bocheński J.M. (1990), Analiza autorytetu, [w:] idem, Logika religii, tłum. S. Magala, PAX, Warszawa.

Bocheński J.M. (1993), Co to jest autorytet?, [w:] idem, Logika i filozofia. Wybór pism, PWN, Warszawa.

Burge T. (1993), Content Preservation, „The Philosophical Review” 102, 4, s. 457-488.

Coady C.A.J. (1992), Testimony: A Philosophical Study, Oxford University Press, Oxford.

Gelfert A. (2014), A Critical Introduction to Testimony, Bloomsbury, London.

Hartmann N. [1925] (1949), Ethik, Walter de Gruyter, Berlin.

Reynolds S.L. (2017), Knowledge as Acceptable Testimony, Cambridge University Press, Cambridge.

Stevenson L. (1993), Why Believe What People Say, „Synthese” 94, 3, s. 429-451.

Trinkaus-Zagzebski L. (2012), Epistemic Authority: A Theory of Trust, Authority and Autonomy of Belief, Oxford University Press, Oxford.

Streszczenie: Świadectwo, autorytet i madrość jako źródła wiedzy

Artykuł bierze pod uwagę zagadnienie źródeł wiedzy. Autor odróżnia pojęcie źródła wiedzy w sensie genezy przekonań od źródła wiedzy w znaczeniu podstawy uprawomocnienia przekonań. Jako źródła wiedzy wymienia percepcję zmysłową doświadczenie wewnętrzne (introspekcję), pamięć, poznanie aprioryczne oraz świadectwo i autorytet. Osobno rozważane jest także pojęcie mądrości. W kwestii natury świadectwa autor argumentuje na rzecz tzw. antyredukcjonizmu, w odniesieniu do natury autorytetu zaś zostaje odróżniony autorytet w sensie deontycznym i epistemicznym oraz sformułowana zostaje teza, że autorytet epistemiczny jest podstawą wszystkich innych postaci autorytetu, to znaczy moralnego, politycznego i religijnego. Mądrość zostaje określona jako aksjologiczna duchowość.

Słowa kluczowe: źródła wiedzy, uprawomocnienie epistemiczne, świadectwo, autorytet, mądrość 
Summary: Testimony, Authority and Wisdom as Sources of Knowledge The article takes into account the issue of sources of knowledge. The author distinguishes the concept of the source of knowledge in the sense of the origin of beliefs and in the sense of the basis for justification of beliefs. As sources of knowledge, he lists sensual perception, inner experience (introspection), memory, a priori cognition as well as testimony and authority. The concept of wisdom is also considered separately. In the matter of the nature of the testimony, the author argues in favor of the so-called antireductionism, and in relation to the nature of authority, authority is distinguished in a deontic and epistemic sense, and the thesis is formulated that epistemic authority is the basis of all other forms of authority, i.e. moral, political and religious. Wisdom is defined as axiological spirituality.

Keywords: sources of knowledge, epistemic justification, testimony, authority, wisdom 